\title{
The Problem of Ideology: Class and Race Politics in Sticks and Bones"
}

\author{
Yasemin Güniz Sertel \\ Department of American Culture and Literature, Faculty of Letters, Istanbul University, İstanbul, 34134, Turkey
}

Copyright $\subset 2017$ by authors, all rights reserved. Authors agree that this article remains permanently open access under the terms of the Creative Commons Attribution License 4.0 International License

\begin{abstract}
This study aims to depict the inability of a traumatized Vietnam War veteran David in his attempts to adapt himself into his former life, family and especially to the cultural and social ideologies of his homeland upon his return to American society in his changed consciousness. On the other hand, his family, the Nelsons, which becomes a microcosm of American society, has also difficulties in embracing this physically and mentally changed man since he has become a threat to the safe grounds of their happy American family ideology. This study attempts to explore how and why David becomes a threat for his family and society from the political aspect. 'The politics of race' and 'the politics of class' will formulate the interpretations of the play as two major modes of political reading.
\end{abstract}

Keywords Political Reading, Politics of Race, Vietnam Syndrome, Social Ideology, Colonizer-colonized Relationship

\section{Introduction}

David Rabe's play Sticks and Bones depicts the encounter between David, the protagonist who returns home from the Vietnam War as a blinded and traumatized veteran, and his family, the Nelsons who represent the happy middle-class American family. In general, the play is not only about the experiences of David in Vietnam but also the main focus is on the protagonist's inability to digest the ideology of American society on his return. On the other hand, the Nelson family also has qualms about accepting David with his physical and spiritual deformities into the happy family frame as a former member since he threatens the safe bases of the happy American family ideology with his behaviors and his new consciousness. Hence, following his homecoming David gets detached from the family as a figure emotionally maimed with self-hatred, loneliness and cynicism. By making use of the politics of race and the politics of class, this study explores the influences and the consequences of David's return on the lives of both his family and himself in his new identity.

Sticks and Bones is a play in two acts with no scene divisions. The setting of the play is the living-room and the upstairs bedrooms of the Nelson family. When the play opens, in all appearance a peaceful mood pervades. A phone call comes announcing the return of David who had been fighting in Vietnam. When David does arrive, the family first note that "something is wrong" [1] with him and next they are shocked to see him blinded. On his part David too experiences some unease, feeling that "the air is wrong, the smell and sound... all wrong." (1: 132) Although at first, both sides try to understand each other, their endeavors are inconclusive. With his changed consciousness David tries to have his family regard reality with fresh eyes, but this 'blindfolded stranger' only disturbs and bores them with his absurd accusations. As the play progresses, the reader/audience learns that David has had a relationship with a Vietnamese girl named Zung who is left behind - probably with child or a baby. As David is tormented by a guilty conscience, the ghostly image of Zung follows him everywhere. David demands his family to see it and accept the presence of Zung in the house and, when she eventually materializes, Ozzie with his racist odium does not hesitate to strangle her. After the killing of Zung, David is also induced to commit suicide and only then the former status quo of the family is restored.

\section{Class Consciousness and the Ideology of American Family}

In his Author's Note, David Rabe elucidates the point with the following comment: "In any society there is an image of how the perfectly happy family should appear. It is this image that the people in this play wish to preserve above all else". [2] As understood from the playwright's words, the play takes the reader/audience to the dream world of a well-off, healthy middle-class American family. Even the setting depicts this archetypal image in its modern decoration. In the play, this bright image is enhanced by the symbolic names of the parents; Ozzie and Harriet Nelson; 
names emblematic of the ideal American family of the 1950 s in the world of entertainment and fantasy, "consciously modeled, by Rabe, on along-running radio and television situation comedy, 'The Adventures of Ozzie and Harriet'." [3] Thus the Nelsons, replicating the popular TV models in the eyes of the audience, assume the same emblematic function of the ideal middle class American family: success oriented, and imbued with wealth and energy; in brief, the living image of the American Dream. However, this pleasant dream is shattered by the homecoming of the eldest son of the family David as a maimed veteran. Physically blinded and spiritually traumatized, David does not seem to fit in with the culturally approved image of the Nelson family. As it is, both David and the Nelsons experience great difficulties in understanding the values and standards of each other. Undoubtedly, "the play tries to show the impossibility of adjustment of the traumatized American warriors to the fantasy world of the happy America. Having lived the horrors of reality, the Vietnam veterans could not adapt to the world of dreams America represented." [4] No wonder, then, that David should lose his sense of belonging as soon as he enters the Nelson abode. He says, "You said 'father', you said 'home'. I don't think so, It doesn't feel right" (1:128) However, it is also clear that that the Nelsons on their part are loath to readmit the disabled David into the family frame as a member. Because, besides being a threat, David's current position becomes the new criteria for judging and evaluating the long-accepted American standards and cultural norms.

\subsection{Happy Family Image as a 'Collective Delusion'}

As a matter of fact, perhaps more than David's physical and mental condition as "somebody sick" (1:120), his re-entrance into the family with a changed consciousness shakes the safe grounds for the Nelson family, since David "brings the war home in the form of a blinded and guilt-ridden veteran." [5] And this war brings forth the clash of disparate consciousnesses and ideologies. Hans Bertens suggests that "subjects cannot transcend their own time but live and work within the horizon of a culture constructed by ideology, by discourse."[6] From the very beginning, it is obvious that the Nelsons have a limited horizon encompassed by the ideology of the American Dream and its cultural discourse, and since they do not intend to cross the boundaries they live happy and contented within them. Marxism, we may recall, would explain the case as a misrepresentation of the world by ideology, whereby the subjects of a society live in a "collective delusion" since "ideology is not so much a set of beliefs or assumptions that we are aware of but it is that which makes us believe that that way of seeing ourselves and the world is natural. In so doing, ideology distorts reality in one way or another and falsely presents as natural and harmonious what is artificial and contradictory. If we succumb to ideology we live in an illusory world". [7] In a similar vein, Marxist philosopher Althusser has interpreted ideology as "the imaginary relationship of individuals to their conditions of existence." [8] And this illusory world would naturally present a "false consciousness". In Sticks and Bones, David "sees his nightmares as reality" whereas the Nelsons "see their dreams as reality." [9] Accordingly, the Nelsons live under a false consciousness and their happy world bounded by a narrow horizon is a fantasy instead of reality. What is more, David too is invited to join this 'collective delusion'. As Harriet suggests, "We're a family, that's all - We've had a little trouble - David, you've got to stop... Just be happy and home like all the others - why can't you? $(1: 163)$

However, this happy family image is only a myth created by the discourse of collective false consciousness which in turn is the product of the American Dream. Since the family members obstinately choose to believe in that myth, they live in a blissful state of denial which blinds them to reality. Beneath this happy and contented façade though, the family members are actually afflicted with a state of alienation which impedes their understanding of each other.

\section{Blindness versus Knowledge: Ozzie Representative of False Consciousness}

Throughout Sticks and Bones, blindness remains a significant motif since the play is about literal and symbolic blindness. David is literally blind whereas the Nelson family - and thus the whole society they represent - is symbolically blind. However, this self-inflicted blindness comes enwrapped in deep irony, since its perpetrator - American society is "extremely content with its own blindness and desperately tries not to lose the bliss associated with that state, that ignorant state of bliss." [10] This society prefers to reject true vision. For sight, or true vision, would invariably lead to "knowledge - of the horrifying truth, of the harsh reality, and of everything that lies outside the merry fantasy world of peace." [11] Unlike sight and truth, blindness brings bliss and happiness to this American world of fantasy.

Another motif in the play seemingly contrary to the above is the validity of knowledge acquired through sight as a product of this same culture. Foucault defines knowledge in terms of discourse. According to him, "knowledge is the product of a certain discourse which has enabled it to be formulated [and] the discourse in question is powerful enough to make us believe that it is knowledge". [12] Within the Nelson family - an epitome of American society 'blindness' and 'false consciousness' are represented in their various aspects by different characters in varying degrees. Ozzie Nelson is the first and foremost representative of false consciousness accompanied by symbolic blindness. According to the dictates of cultural discourse, being a male member and a father, he is the head of the family, thus assuming responsibility and patriarchal authority over the Nelsons. In the play, a significant means for Ozzie to assert his so-called functional existence is to define himself in materialistic terms. Ozzie being a representative of the consumerist American society, it is not surprising to the 
reader/audience that Ozzie should define himself in materialist terms. It is also significant that Ozzie derives his authority and power from his property ownership, thus he makes an inventory of everything he owns with their prices. In a way, the abundance of his assets provides for him a means for quenching spiritual starvation. However, as the play progresses, it is not difficult for the reader/audience to realize the impoverished role of the father figure beneath his authoritative and strong appearance. His ideology has induced him to believe mistakenly that he is wealthy and powerful and hence, whole and real. Yet, as a victim of his false consciousness, he is no more than a helpless nonentity. He has realized that nobody in the family takes him seriously or even really cares for him. As he mentions, "I fear... Because I know the time is close when I will be of no use to any of you any longer". (2:203) Therefore, far from holding to the stable and authoritative position of the patriarch in the family circle, he dwindles into the role of an insignificant and irresponsible weakling.

As a matter of fact, Ozzie's false consciousness has been the product of his acquiescence in the dominant discourse and acceptance of its guidance. In this connection, Hank, a former friend of Ozzie, acts out the role of the surrogate father for Ozzie and has a great influence on the significant choices in Ozzie's life. According to the dictates of the ruling cultural discourse, we can say that it is Hank who directs Ozzie in the path of life and who makes for him decisions. As Ozzie suggests, "I had no choice... I thought, and noone remained to test me. I didn't even know what I was doing... Hank was there... He stands distant, ordering" (1:168). It is also Hank who chooses Harriet as a life partner for Ozzie. Therefore, Hank proves himself as the embodiment of the dominant discourse in force in that society and, the influence of Hank in Ozzie's life becomes a negative impact depriving him of his capacity of thinking which is tantamount to depriving a person of his liberty, since "the liberal humanist" agenda has it that, "we are essentially free and can remain free as long as we can think". [13] As a result of Hank's influence and surveillance, Ozzie cannot develop a "subjective consciousness"; a concept interpreted as "ideas and actions of our own, which depend on us, not determined by forces over which we have no control."[14] Victimized by Hank's - thus the dominant discourse's- control over his life, Ozzie cannot develop a mature identity. Hank's power over Ozzie can also be likened to the influence of "body of knowledge" in Foucaul's terms. Defining knowledge as a discourse of expertise, its influence on the individuals can be explained in the following way: "Because of their claims to expertise such discourses then go on to determine the way we talk and think about the field in question... and persuade us to keep ourselves and others under constant surveillance. Since we are all extensions of the discourses that we have internalized, we ourselves constantly reproduce their power, even in our intimate relations." [15] It is obvious that Ozzie internalizes the role and its conditions imposed on him by Hank. Ozzie's identity is constructed around this internalization and thus, the power and authority of the dominant discourse is re-produced. When Ozzie uses his volition, he is "acted on by the... system." [16] This situation can also be regarded as a case in point for Gramsci's concept of hegemony, which he explains as "the power of ideology" eliciting "the spontaneous concept given by the great masses of the population to the general direction imposed on social life by the dominant fundamental group." [17] In this case, of course Ozzie represents the "great masses of population whereas Hank stands for the "dominant fundamental group". Hence, victimized by the American ideology Ozzie's life is wasted and thus, contrary to his stable appearance he becomes an unfree, discontented and immature individual.

\subsection{Harriet and Rick as Examples of 'Concrete Subjects'}

Another victim of the dominant discourse deployed to produce false consciousness within the Nelson family is the mother figure, Harriet Nelson. She strictly obeys the dictates of the false consciousness implanted in her by the dominant discourse. Therefore, she cannot develop her proper /subjective consciousness at all. One of the most significant reasons of Harriet's inability to construct a subjective consciousness is that she has to develop first a "subject position" in that society, which she never did or could not. Harriet's strict obedience of the dictates of her subject position, makes her "a concrete subject" which can be explained in the following way: "The ideology addresses us as concrete subjects... In so doing, it may 'interpellate' us in different social roles that we play, or the different 'subject positions' that we occupy. One and the same woman could be 'interpellated' as a mother, as a member of a particular church, and so on. The way ideology addresses us creates that subject position for us and... convinces us that we are whole and real, that we are the 'concrete subjects' we want to be." [18]

Throughout the play, Harriet maintains her subject position by internalizing her gender role imposed on her by the cultural discourse. This gender role dictates her to be a perfect mother and wife within the boundaries of the private-service sphere. Therefore, in that limited sphere her role is to be the nourisher of the family. In order to experience wholeness, she devotedly takes care of her children and husband. She experiences self-gratification only by cooking and providing food for the family. Thus, throughout the play, she is rendered in the act of serving cakes, chocolate puns, ice cream and fruit juice. Even at the moments of crisis, she appears on stage with a tray full of various food stuff. Although Harriet is aware of her subject position, the family members remind her of her place by constantly sending her to the kitchen even during the most important incidents. Yet, on another level, her cooking and serving food signify the spiritual hunger of both herself and her family. She tries to quench the spiritual cravings of her family with the rich foods she offers them. As a matter of fact, throughout Sticks and Bones, the role of Harriet as nourisher and healer achieves a grotesque turn within the patriarchal system of values. She has been rendered as a menial figure whose services are not appreciated, though 
they are essential for the maintenance of life. Despite all this however, Harriet is allowed to link up with the family's collective delusion by regarding herself as an indispensable member of the family.

The last member of the Nelson family who is another happy victim of the cultural ideology is the junior son, Rick. Since Rick experiences the collective delusion to a great extent, he is always unconsciously happy; "everything is all right", and "there's no problem" for him. His only responsibility is to immortalize the happy moments of the family by taking photographs with his camera. Living in a world of delusion, he is disinterested in the events going around him and is incapable of comprehending the family problems. He even sees David as "healthy" whereas David is regarded as "somebody sick" by the other members. With his guitar in his hands he wanders around as a spiritual drifter. However, in spite of Rick's irresponsible attitudes and unconcern towards his family, he is the favorite son of Ozzie and Harriet since he is always contented, happy and joyful. $\mathrm{He}$ is an ideal figure to complete the blithe image of the family in their collective delusion. While Rick brings happiness to the family with his merry manners, David brings dilemmas, unhappiness, restlessness and distress. David firstly criticizes and then attacks the ideology of his parents, therefore, he becomes a threat to the well-being of the family.

\section{Hegemonic Culture versus Sub-Culture}

When David returns home from Vietnam, at first the family happily welcomes him and then expect from him to wipe away all his memories of Vietnam and resume his life course in his own culture where he had left it. For example, Harriet tells, "It must be so wonderful for you to be home. Just know that you're home and safe again. Nothing else; only that we're altogether, a family." (1:141) As a matter of fact, the expectations of the family from David represent the way the dominant discourse monitors the actions of those individuals under its hegemony. And such an expectation defines the process of how "power works through discourses and, like ideology, gives the subject the impression that to comply with its dictates is the natural thing to do and thus a free, autonomous decision." [19]Yet, this situation can be accepted as another collective delusion of the society in question. However, David, during his absence from this society has been exempt from the impact of its ideology and, has developed a subjective consciousness in the course of his confrontation with another culture. With this new consciousness David is able to reject the old ideologies he was administered. As he says, "there were old voices inside me I had trusted all my life I didn't know I shouldn't hear them, and now I know that I was not awake but asleep". $(1: 177)$

David begins to criticize the ideology of the society embodied in the life style of the Nelson family. In his physical blindness he tries to show his family how they in turn are mentally blinded to reality. He tries to show them the big illusion they are living in and declares his desperate desire to change this order: "This house is a coffin. You made it big so you wouldn't know, but that's what it is, and not all the curtains and pictures and lamps in the world can change it." (1:194 -195) These attitudes of David signal his intention to subvert the conventional order of society. His actions are in fact, a challenge and resistance to the powerful hegemony of the dominant discourse. Towards the end of the play, he makes a confession to that effect: "I wanted... to change... to kill you... all of you" (2:222) David's stance is proof to his desire to change and re-construct the actual hegemony as well. This character's case can be taken as an example for Raymond Williams's interpretation of the concept. According to Williams, "hegemony is not singular... its own internal structures can be continually challenged and in certain respects modified." [20] David's situation can also be interpreted as the "emergent strain" which offers an alternative perspective to the dominant discourse because "the dominant culture is always under pressure from alternative views and beliefs". [21] When the family realizes that David is serious in his destructive intentions they turn defensive and make it clear to him that their order cannot and shall not be changed. They are happy in their collective delusion and they will continue to live that way. They tell, "Let us alone. We're sick of you. We don't wanna talk anymore about all the stupid stuff you talk. We want to talk about cake and cookies and cars and coffee." (2:216-217) The constant struggle between David and the family can be explained -in Raymond William's assertion "with its far more flexible notion of ideology, hegemony and counterhegemonic tendencies which struggle with each other in a... culture [and are] constantly in motion." [22] Although David is not the winner of this struggle between 'hegemony' and 'counterhegemony' he is presented to the reader/audience as a nonconformist character going "against the grain, offering dissidence that makes us hear the socially marginalized and expose the ideological machinery that is responsible for their marginalization and exclusion." [23]

\section{Politics of Race and 'The Other'}

Besides the 'politics of class' which accompanies the interpretation of Sticks and Bones up to this point, a 'politics of race' can also be observed throughout the play centered on David's relationship with the Vietnamese girl, Zung. The invisible Zung who symbolizes the transformed consciousness and guilty conscience of David is the surreal element in the play. Zung as the representative identity of a minority group, a member of a different culture and an alien race can be accepted as 'the Other'. She is different and her difference is accepted as a potential threat to the Nelsons and their ideology. From this perspective, she is also the embodiment of "the emergent strain" in Raymond William's terms, the alternative view which mounts an immediate 
attack on the dominant culture. The social order and the ideology of the family are threatened when they realize David's inclination to and intentions about Zung because, the probable unity of David with Zung would be inimical to the cultural ideology that used to inscribe the conventional institutions of marriage and family. Thus, both as an act of refusal and a defense mechanism, the racial hatred of the family members is directed towards Zung. As Ozzie outcries: "YOU MAKE ME WANT TO VOMIT... I MEAN I JUST CAN'T STOP THINKING ABOUT IT. LITTLT BITTY CHINKY KIDS HE WANTED TO HAVE." (1:173)

\subsection{The Relationship between the Colonizer and the Colonized and 'Colonial Hybridity'}

In Vietnam, the relationship between David as an American soldier and Zung as a native girl reminds the reader/audience of the relationship between "the colonizer" and "the colonized." As already mentioned above, David has developed a new consciousness and constructed a new identity for himself during his stay and experiences in Vietnam. This changed self is structured partly under the influence of Zung; in other words, drawing on Lacan's views, his 'identity is constructed in interaction with 'others' and with 'the Other'."'24] At this point, the inevitable experience between colonizer and colonized should be mentioned since "the identity of the colonizer... cannot very well be separated from that of the colonized, or at least from the supposed identity of the colonized... Instead of being self-sufficient with regard to his identity, the colonizer at least partly constructs it through interaction with the colonized". [25] From this perspective, Zung's power over David and his new consciousness and identity becomes an implacable influence. As for David Zung is "the thing most possibly the value in my life. She's all of everything impossible made possible". (1:177) The influence or power of Zung over David can also be interpreted in the light of Frantz Fanon's observations about the relationship between the colonizer and the colonized. Fannon suggests that "the native takes pride in demonstrating that he has assimilated that is mastered - the culture of the occupying power." [26] Yet, in this case the proud native is not a 'he', but a 'she.' In other words, if David stands as the representative of "occupying power," Zung the she-native has clearly overpowered him.

Another trope that may be relevant to the relationship between David and Zung is the concept of "colonial hybridity" in which "the cultural interaction of colonizer and colonized leads to a fusion of cultural forms because it signals its 'productivity', confirms the power of the colonial presence".[27] In the context of the play, an instance of colonial hybridity might be the possibility of a hybrid grandchild being born to the Nelson family. However, Harriet's reaction to this possibility reflects both her racist odium towards and also her fear of being conquered by the 'Other': "It is we who disappear. They don't change, and we are gone. It is our triumph, our whiteness. We disappear...
They take us back and down if our children are theirs - it is not a mingling of blood, it is theft. (2:208-209) This possibility is the biggest threat to -or in Raymond Williams's terms the "pressure of the emergent strain" on - the dominant culture, and it can never be tolerated. In order to thwart this 'loathsome' possibility, Zung is strangled to death and David is invited to commit suicide so as to wipe out all traces of this dire prospect. Thus, David kills himself with the whole-hearted support of the Nelsons as in a family ritual. Following David's suicide, the preservation of ideology and the maintenance of order and harmony in the family are schematized by the playwright David Rabe in the Author's Note in the following style: "At the start, the family is happy and orderly, and then David comes home and he is unhappy. As the play progresses, he becomes happier and they become unhappier. Then, at the end, they are happy. [28]

\section{Conclusions}

The end of the play takes the reader back to the very beginning when the Nelsons happily experience the state of 'collective delusion'; an illusionary and a dreamy state where their mythic fantasies are transformed in to a false reality. In this state of delusion which is a product of the false consciousnesses of the family members, David or Zung can no more be a threat for the Nelsons' happiness since they are terminated, left behind and forgotten as parts of an unwanted nightmare. As a matter of fact, the happiness or false illusion gained by the maintenance of the old order can be interpreted as a self-imposed imprisonment suffered by individuals since "in the modern world we, the citizens, are 'the bearers' of our own figurative, mental, imprisonment." [29] For the same situation, Althusser comes up with a similar diagnosis: "We are complicit in our own confinement."[30] In like manner, at the end of the play the Nelsons, after obliterating all the threats inimical to their ideal family image, are doomed to be imprisoned in their wrong ideology and remain mired in their false happiness.

\section{REFERENCES}

[1] Rabe, David. Two Plays by David Rabe. The Viking Press, New York, 1979, 132. (All the quotations taken from the play Sticks and Bones belong to this edition and the quotations from the play are given in round brackets in this paper.)

[2] Rabe, David. Two Plays by David Rabe. The Viking Press, New York, 1979, 225.

[3] Bigsby, C. W.E. Modern American Drama, 1945-1990. Cambridge University Press, New York, 1992, 257.

[4] Tekinay, Asl1. Contemporary American Drama, 1960-2000. Bogazici Universitesi Matbaasi, Istanbul, 2001, 39.

[5] Berkowitz, Gerald M. American Drama of the Twentieth Century. Longman, London and New York, 1992, 142. 
[6] Bertens, Hans. Literary Theory - The Basics, Routledge, London and New York, 1995, 185.

[7] Bertens, Hans. Literary Theory - The Basics, Routledge, London and New York, 1995, 84-85.

[8] Althusser, Louis. Lenin and Philosophy and other Essays, New Left Books, London, 1971, 18.

[9] Bigsby, C. W.E. Modern American Drama, 1945-1990. Cambridge University Press, New York, 1992, 258.

[10] Tekinay, Asl. Contemporary American Drama, 1960-2000. Bogazici Universitesi Matbaasi, Istanbul, 2001, 39.

[11] ibid. 39.

[12] Foucault qtd. in Bertens, Hans. Literary Theory - The Basics, Routledge, London and New York, 1995, 155.

[13] Bertens, Hans. Literary Theory - The Basics, Routledge, London and New York, 1995, 84.

[14] ibid. 84.

[15] ibid 156.

[16] ibid 86.

[17] Gramsci qtd. in Bertens, Hans. Literary Theory - The Basics, Routledge, London and New York, 1995, 88.

[18] Bertens, Hans. Literary Theory - The Basics, Routledge,
London and New York, 1995, 87.

[19] ibid. 179.

[20] Williams, Raymond. "Base and Superstructure in Marxist Cultural Theory" in Kiernan Ryan (ed). New Historicism and Cultural Materialism: A Reader, Oxford University Press, New York 1996, 22.

[21] Bertens, Hans. Literary Theory - The Basics, Routledge, London and New York, 1995, 186.

[22] ibid.89.

[23] ibid.187.

[24] ibid. 207

[25] ibid. 207

[26] Fanon qtd. in Bertens, Hans. Literary Theory - The Basics, Routledge, London and New York, 1995, 106.

[27] Bertens, Hans. Literary Theory - The Basics, Routledge, London and New York, 1995, 209.

[28] Rabe, David. Two Plays by David Rabe. The Viking Press, New York, 1979, 226.

[29] Bertens, Hans. Literary Theory - The Basics, Routledge, London and New York, 1995, 151.

[30] ibid.151. 